1977-08-01

\title{
Drosophila pseudoobscura of the Great Basin
}

Monte E. Turner

Brigham Young University - Provo

Follow this and additional works at: https://scholarsarchive.byu.edu/etd

\section{BYU ScholarsArchive Citation}

Turner, Monte E., "Drosophila pseudoobscura of the Great Basin" (1977). Theses and Dissertations. 7908. https://scholarsarchive.byu.edu/etd/7908 
OBSERVATINS ON THE HIB ENATION OF CULEX TARSALIS COQUILEETT

IN UTAH VALLEY, UTAH

\author{
A Thesis \\ Presented to the \\ Department of Zoology and Entomology \\ Brigham Young University
}

In Partial fulfillment

of the Requirements for the Degree

Haster of Science

by

Dennis

September 1960 
This thesis, by Dennis w. Trent, is accepted in its present form by the Departwent of Zoology and Entonology of Brigham Young University as satisfying the thesis requirement for the degree of Haster of science.

Typed by Mrs. Paul Harding 


\section{ACKNOWLEDGINENTS}

I am Indebted to Dr. D. Elden Beck, Associate Professor of Zoology and Entomology, for the countless ways in which he has helped me throughout this project and other graduate study. He has almays been free with his time, helpful suggestions and a constant source of enthusiasm.

I should Iike to thank Dr. Don H. Larsen, and Dr. Richard D. Sagers for their suggestions and service as members of the graduate comittee, as well as for their atimalation and instruction in the field of microblology.

Further, I would like to acknowledge the assistance given me by the National Institutes of Health, Public Health Service, Rocky Mountain Laboratory. I would like to thank Dr. CarI M. Ecklund for permission to use materials and facilities within his laboratory to attempt 1solation of WEE virus from hibernating mosquitoes. To Dr. Leo A. Thomas I express sincere appreclation for his interest and assistance in arranging for isolation studies to be completed at the laboratorys and whose ingtruction and enthuaiasm has been an inspiration.

To Dr. C. Lynn Heyward, Dr. Dorald H. Allred, Dr. Stephen L. Wood and Dr. Cluff Hopla I express thanks and appreciation for their assistance in the execution of this project.

For permission to establish weather instruments and a light trap on their property I thank $\mathrm{Hr}$. and Mrs. James kendenhall. 
I an also very grateful to Bert L. Taylor for drafting and preparing graphs presented in this thesis.

This investigation supported by Brigham Young University Research Funds.

To student associates, I would like to extend a word of appreciation for their constructive suggestions and enthuslasm. Especially to Rlchard G. Robertson I am grateful for his help, suggestions and constant stimulation in the fleld of medical entonology.

Finally, I shall always be grateful to my wife Joyce for her patience, understanding and support in completion of this project and preparation this nuscript. Without her support and inspIration this study and further graduate work would be impossible. 


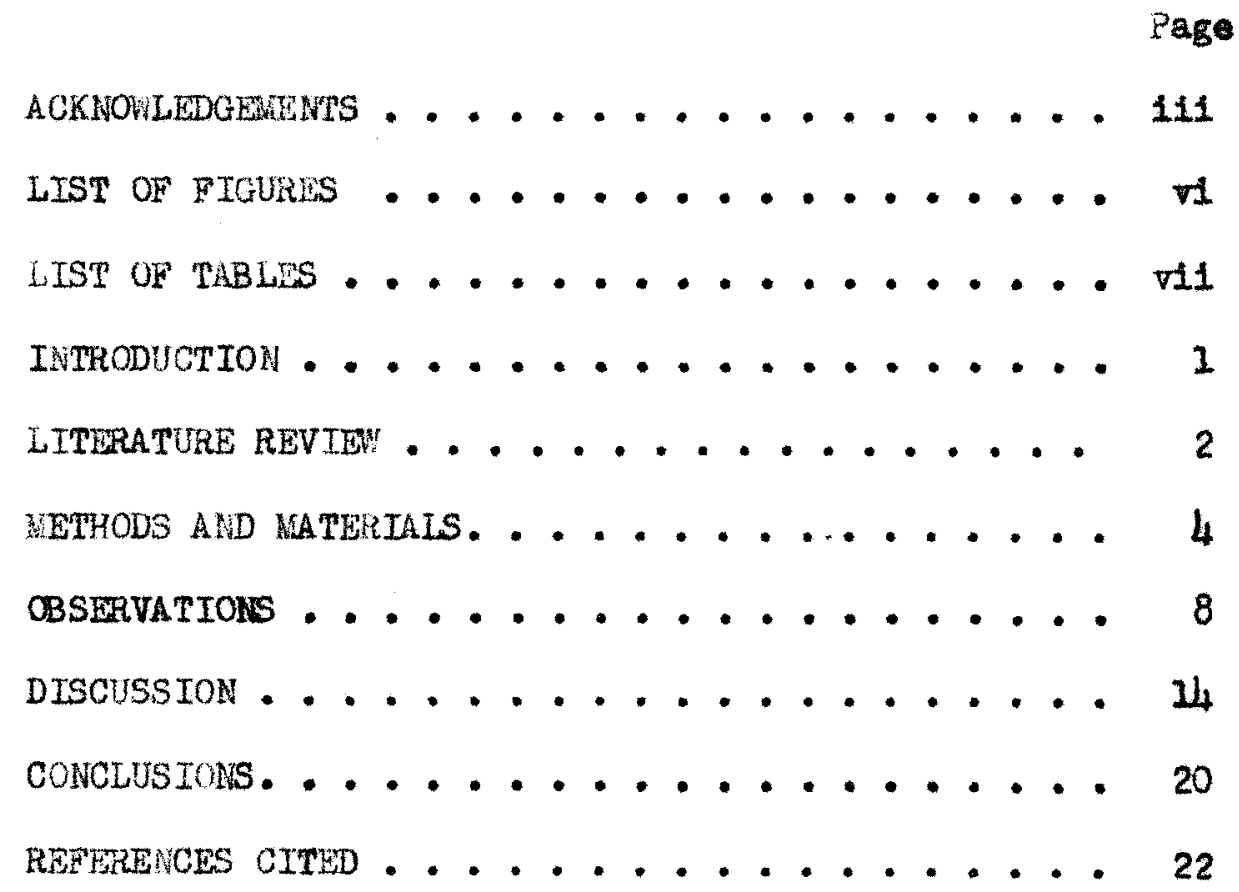




\section{LIST OF TABLES}

Table

Page

1. Collections of hibernating $G$. tarsalis, number of pools and virus resulto. . . .........

2. Light trap collections of $\mathrm{Q}$ tarsalis at loshen and the Kendenhall Ranch ........... 
LIST OF FIGURES

PIgure

Page

1. Map of hibernation sites............ 25

2. Mininum-maximum atmospheric temperatures recorded at the kendenhall Ranch near the Landrock site. . . 26

3. Seasonal variation in soil temperatures at the 21 inch level, average temperature of rocks from which hibernating $C$. tarsalis were collected and mosquito hibernation depth................

4. C. tarsalis hibernation temperatures recorded during this and other inrestigations........... 
LIST of Howns

Peure

1. dap of hibermation altea.............. 5

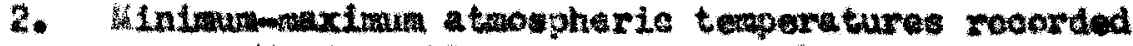
at the indenbill Ranch near the Lardroek ste. . 26

3. Seagonal variation in anll temperatures at the 21 thoh iavel, average temparatare of rocks row wilch

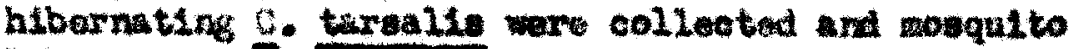
hiberation Jepth. ................ 27

4. C. tarselia hibemation temparatures reconded duming Eis an other investigationa............ 


\section{IITRODUCTION}

Gulex tarsalis Coquillett is a common evening pest mosquito throughout the summer in most of temperate Western North America. Present evidence indicates this mosquito as the principal naturally infected vector of western equine encephalomyeltic (wes) viruses. Certain interrelationships of wEe epidemiology and tarsalis bionomics are basically understood, however, in areas where winters are severe little is known of tarsalis hibernation, and the survival mechanism for WEe viruses is unknown. If sufficient virus survives in the hibernating mosquito to infect vertebrate hosts upon spring emergence of the vector, an extremely important interrelationship between the two phenomena exists. The possibility that virus survives only in the vector during the winter is doubtful; however, a thorough understanding of C. tarsalis hibernation and its relationship to WEE survival mast be developed before an accurate evaluation of the mosquito-Wise virus reservolr concept can be made.

The purpose of this study, conducted from 1 September 1959 to 20 liay 1960, was to gather ecological information on the hibernation of Culex tarsalis in Utah Valley, and secondly to collect pools of hibernatine tarselis and determine the index of infection, if any by WEE Viruses. 


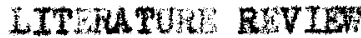

Durlns the colder months (December and Janury) in californis Reeves ot 1. (1948) jortonoon (1953) and Looms and oreen (1959), abserved $\mathrm{G}$. taralie overwintering in tree stuaps, hollow logs, brush piles and wld rodent burrows. In coloredo, small mabers of this spec1es were observed to hibernete in rodent burrom (Bennington et al., 1958). Hawnon et al., (1942), Saith (1955), weener (2952) and Dow eㅡ al. (1956) reported tereal18 hibernating 1 r. food storage cellara In kashington, Hontan, western Hebraska and horthern Utah reapectively. Blackare and tinn (1956) collocted 1,361 hibernating specinen from abandoned mines in Colorwio. Investigation of abandoned mber in Horthorn Utah Indicated the species did not avecessfuIly hibernate In these ofreunatanes, although a fow epecinens were obmerved here during most of the later (Dow ot al., 1956). Hibermation of thie motgat to in rock plies at the base of rolcanic cuterops in the Columbla tiver Basin dascribed bysh al. (1958). In Central Uth, Taylor (1959), reported Q. taraals, from talus slidea and rock piles in the early ppring, at the base of mountalns surrounding Utah ralley.

Culex tareal1s has been ldentified as the principel rector of WES virusen in mang parts of the Undted States (Hess and Holden, 1958, Eoklund, 2960). Hamon et al. (1942) in discusaing the posstbility that viral infected $\mathrm{G}$. tarsalls may serve as an overwintering nechenisa 
for WEE viruses state, "Another factor favoring the interrelationship of $\mathrm{c}$. tarsalis and the endemic situation is the hablt of adult winter hibernation. In this manner infected individuals might pass through winter and reestablish the infection in vertebrate hosts the following spring". Several attempts have been made to verify this hypothesis, such as those by Hamon ot al. (1945), Rush et al. (1958) in Washington; Hamnon et al. (1945), Hamon and Reeves (1947), Reeves et al. (1958) in Callfornia; Keener (1952) in Western Nebraska and Blackmore and Winn (1956) in Colorado. A single 18olation of $\mathrm{WEE}$ virus from hibernating tarsalis in Colorado (Blackmore and Winn, 1956) is the only positive evidence to aupport the theory; however, in California, where they do not enter true hibernation, the virus has been isolated in all winter months except December (Reeves et al., 1958). 
MATERTALS AHD NETHODS

\section{Fleld Procedure}

During September of 1959 a survey of one previously suspected and other possible hibernation sites was made, and four representative areas in Utah Valloy were selected for extensive observation. These were: (1) American Fork Canyon in the Timpanogos Cave quadrangle, (2) Landrock in the Saratoga Springe Quadrangle, (3) Rock Caryon in the Bridal Veil Falls quadrangle, (4) Wara Springs wountain in the Santaquin Quadrangle * (F1gure 1).

Ecologieal data on the hibernation of Culex tarsalis rere gathered during the fall and winter by weekly visits at Landrock and biweekly inspections at all other areas. Prembibernation observations were made by inspection of farm bulldings, sweep-net collections from vegetation, and periodic probing excavations to determine date of entry into hibernation. Systematic excavations were conducted during the winter to determine presence and behavior of the species and to collect spectmens : or viral analysis. Detection of early spring emergence from hibernation accomplished by excavation. To detect activity of emergent hibernators in the valley, light traps were established at the liendenhall Ranch one mfle north of Landrock, and at Geological Survey Topographlc Maps, 7.5 mimute series, scale 1:24,000. 
Goshen two miles west of the Warm Spring kountain site. Weekly Inspection of farm buildings in Goshen, American Fork and Landrock areas were conducted from 23 March to 20 April. Systematic surveys of typical larval habitats along the west shore of Utah Lake from Pelican Point to the Lehi pumping plant, Jordan Narrows and American Fork were conducted weekly from 28 March to $20 \mathrm{May}$ to determine the appearence of larvae.

Field Materials

Weather Instruments. Continuous recordings of ternerature and bumidity were established at the Mendenhall Ranch near Landrock. Recordings of atmospheric temperature and relative humidity were accomplished by the use of a Bendix-Friez Hygrothermograph. Sling psychrometer readings were taken at various intervals to chock accuracy of hygrothermograph readings. Soll temperatures were read weskly from a Taylor minimum-maximum thermometer suspended inside a cement pipe buried 21 inches in the soil with the top five inches of the pipe filled with insulation and soil.

During weekly excavations at Iandrock, and biweekly excevations at other sites, air temperature and relative humidity were obtained by use of a sling psychrometer. During excavation at 211 sites the temperatures of rocks, upon which hibernating $\underline{Q}$. tarsalis were found, were measured by a Cole-Parmer Thermister.

Lifht Trap. Standard New Jersey light traps were used to determine 


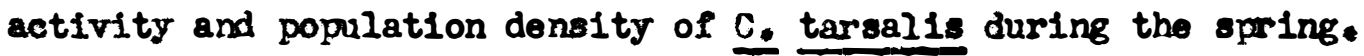

\section{Iaboratory Procedure.}

Aspirator collections of sosquitios talen from a fiven site, on a Given date constituted a pool. Nosquitoes removed from the under surface of rocks durirte an observation were placed in sterile 10 dram glass vials, given a collection number and placed on ice until examined under the dissecting microscope. Specinens kept alive for periocis of 24 hours to two weeks at $40^{\circ} \mathrm{F}$ were anesthetized with chloroform but not killed, and dissected in order to determine the presence of developing ova, undigested blood, and fat bodies. The emount of fat body present was determined by the relative distention of the abciomen. Pools of mosquitces to be examiner for virus sere sealed in sterile glass vials and stored on dry ice untll anelyses mere made.

Individuel pools of frosen mosquitoes to be tested for virus were ground in porcelatic mortars using mosquito diluent ( $20 \%$ normal rabbit seruil in $0.85 \%$ NaCl plus 300 units of peniclluled and 300 morograms of streptomycin per ml.). The ausponsion was then placed in the refrigerator for tro hours for antibiotic action and to allow coarse particles of mosquito tiesue to settle. The suspension was then rovered from refrigeration and the supernatant inoculated into a litter of four-day old albino Swiss mice. Each mouse received $0.05 \mathrm{cc}$ by intraperitoneal inoculation. Four days following inital inoculation of mosquito serum, braine from three mice of the original litter were harrested, pooled and passed serially to a new litter. All mice were observed fourteen days for slgns of seningo-encephal1tis, euch as 
spastic muscular contractions and paralysis, followed by prostration and death; healthy nice were discarded at the end of the observaion period.

\section{Laboratory Material}

Hce. A strain of white Swiss mice (Rocky Mountain Laboratory Strain) was used in the attempt to isolate virus. This otrain has been maintained at the Rocky Hountain Laboratory for 21 years. A mouse Iitter, as used in the 16olation studies, consisted of six fourday old mice. During this investigation 46 litters of mice were used. 
CBSERVATIONS

Fleld Ooservations

Description of hibernation habitats. Hibernation habitats included both artificial and natural talus slides at the base of mountalns which surround the valley. Brief description of each site is given below.*

1. Timpanogos Cave Juadrangle, Vasatch Range, American Fork Canyon, Range 2 East, Township 4 South, Section 32 , elevation 5,100 feet. Natural north facing limestone talus slope at the mouth of American Fork Canyon. Dominant vegetation was Currant (Ribus cereum) and Choke Cherry (Prumus malanocarpa).

2. Saratoga Springs quadrangle, Lake Mountains, Range 1 West, Township 6 South, Section 2, Landrock, elevation 4,800 feet. East facing artificial limestone talus slope one and one half miles vest of the west shore of Utah Lake. Dominant vegetation was sage Brush (Artemesia tridentata) and Twisted habbit Brush (Chrysothamnus spp.).

3. Bridal Veil Falls quarangle, Cascade Range, Range 3 East, Township 6 south, section 28, elevation 6,600 feet. Southwest facing natural feldspar talus slope about one mile east of the mouth of Rock Canyon. Dominant vegetation was Scrub Dak (quercus gembeli1).

4. Santaquin Quadrangle, Warm Spring Mountain, Range 1 East, : ownship 10 South, Section 8, Tarm Spring hountain, elevation 4,700 feet. West facing artificial limestone talus slope directly east of Goshen Ponds. Dominant vegetation was Rabbit Brush (Chrysothammus spp.).

Pre-hibernation observations. Culex tsrsalis were found to rest

in vegetation near the hibernation site during warm afternoons $\left(90^{\circ}-74^{\circ} \mathrm{F}\right)$ in September and the first week in October. In the evening as the sun's

Topographic description of these sites was taken from United States Geological Survey Topographic Maps, 7.5 minute series, scale $1: 24,000$. 
rays left the valley and the atmospheric temperature decreased $4^{\circ}-7^{\circ} \mathrm{F}$ the mosquitoes were observed to leave the vegetation, migrate to the talus slope and crawl under the upper rocks in the talus hibernation habitat. If specimens were disturbed in vegetation or during excavation they would fly away rapidly. During the cold and storny weather in October and the first week in November 1959 this species, along with Anopheles freebornt, was observed under rocks at the upper part of the talus slope. Then minimum temperatures fell below $40^{\circ} \mathrm{F}$ mosquitoes were no longer observed in vegetation but during the warm part of the day would appear on top of rocks at the hibernation site.

Blood engorgement, as noted in oweep-net collections, declined from $23 \%(11 / 47)$ to $4 \%(1 / 27)$ during September. October 27 was the last date an engorged specimen sollected. Abdominal fat bodies were first observed in specimens collected on 4 september. The number of mosquitoes showing fat bodies gradually increased from $2 \%(1 / 29)$ to $87 \%(29 / 33)$ during September and the first meek in October. All specimens collected after 10 October showed extensive abdominal distention due to fat body development.

Ground temperatures during the pro-hibernation period, I September to 6 November, declined from $76^{\circ}$ to $52^{\circ} \mathrm{F}$ expressing a 24 degree change In the period (Figure 2). Mr temperatures fluctuated from a maximum of $90^{\circ} \mathrm{i}$ to a minimum of $26^{\circ} \mathrm{F}$ during September and October; the mean temperature decreasing from $68^{\circ}$ to $36^{\circ}$ (Figure 2). Relative humidity during the perlod ranged from $74 \%$ to $10 \%$ with little moiature falling during the entire fall.

Hibernation observations. Throughout Utah Valley culex tarsalis 
entered hibernation between 1 and 7 Hovember 1959 when atmospheric temperatures ranged between $60^{\circ}$ and $15^{\circ} \mathrm{F}$ and relative humidity fluctuated between $12 \%$ and $83 \%$. Hibernating specimens were found in talus slidea clinging to the underside of rocks below the frost line and lmediately beneath a layer of rocks moist with frost. Depth of hibernating specimens varied from one to five feet during the winter, however, at an one time mosequitoes were found to occupy approximately the same level within the hibernation habitats (Figure 3).

Hibernating specimens looked like adults newly emerged from pupation. They were quiescent and their abdomens were filled with fat bodies. During the last three weeks of hibernation specimens appeared about the same as those obscrved earlier in the study, however, excavation would listurt the mosquitoes and usually they would make some attempt to escape.

The temperature of rocks upon which hibernating C. tarsalis were found varied from $29^{\circ}$ to $38^{\circ} \mathrm{F}$ over the hibernation period (Figure 3). Temperatures during the first 11 weeks of hibernation were fairly stable, fluctuations were only gradual and slight after the first two woeks of hibernation. Rock temperatures fluctuated irregularly from $30^{\circ}$ to $38^{\circ} \mathrm{F}$ during harch and returned within one degree of the tempexature recorded the first week of hibernation. A tmospheric temperatures outside the hibernation habitat the first 9 weeks varied from a high of $72^{\circ}$ to a low of $-16^{\circ}$, the lowest temperature of the winter. During the next two months, January and February, the mean temperature fluctuated between $24^{\circ}$ and $36^{\circ} \mathrm{F}$. Minimum temperatures during this perlod remained well below freezing 
wile the maximums were only $10^{\circ} \mathrm{F}$ to $16^{\circ} \mathrm{F}$ above the freezing point. In Harch atrospheric temperatures abruptly warmed to an average of $50^{\circ}$, however, minimum temperatures remained below freezing while afternoon temperatures soared into the high 60 's F (Figure 2).

Soll temperatures reflected the change in atmospheric temperature, however, remaining $12^{\circ} \mathrm{F}$ warmer during the firgt 9 weeks of hibernation. Soil temperatures declined fram $52^{\circ}$ to $20^{\circ} \mathrm{F}$ during November, December and Jamuary with a gradual warming from $30^{\circ}$ to $53^{\circ} \mathrm{F}$ recorded during February and March. During the last week of hibernation soll temperatures increased rapidly from $41^{\circ}$ to $51^{\circ} \mathrm{F}$ thu becoming $13^{\circ} \mathrm{F}$ rmer than rock temperatures recorded for the last hibernating mosaultoes (Figure 3). Collection of hibernating C. targalis for virus studies was begun on 2 January 1960 and continued weekly unt1l spring mergence from hibernation was apparently complete (Table 1 ).

Margenoe. Emergence from hibernation was first noted at Landrock on 22 March 1960. An immediate search of other sites Indicated energence had been general, as 21 hours of excavation failed to yield a single specimen. Outside atmospheric temperatures during the week of 22 March 1960 were at a minimum of $30^{\circ} \mathrm{F}$ and a maximum of $70^{\circ} \mathrm{F}$ suggesting that the species is able to endure below freezing temperatures out of the hibernation habitat. Light traps established at the Kendenhall Ranch and Goshen were negative during the first woek, 20-26 March. Farm buildings near Landrock, American Fork and Coshen were also searched with negative results.

On 30 iarch three female tarsalis were collected in the Goshen Ifght trap and on 2 April two were collected at the Hendenhall Ranch In a light trap. The abdomens of all five specimens appeared empty. 
There no indication of undigested blood, fat bodies or developing ova. A search of farm bulldings throughout the valley falled to produce mosquitoes of this species. Inspection of typical larval habitats in American Fork and along the west shore of Utah Lake Iikewise proved negative for tarsalls, although Aedes dorsalls larvae were collected in shallow ponds 100 yards frot the lake shore.

Engorged specimens were first collected in chicken coops at American Fork and Goshen during the first week of April, twelve to fourteen days following emergence. Four blood engorged mosquitoes were collected in American Fork on 4 April, and the following evening in Goshen three more were collected. Light trap collections during the week of 3 to 9 April produced two specimens in Goshen and one at the Lendenhall Ranch Table 2 . A thorough survey of larval habitats In Goshen Valley, American Fork and Landrock were negative for tarealis; howevor, Aedes dorsalis larve were becoming widespread. Culex tarsalis larvae were first collected on 11 April in American Fork. Six third instar larva were collected in a shallow pool, Indicating larva appeared sometime earlier but had not been observed. Light trap collections of three and five specimens were taken at coshen and at the llendenhall Ranch respectively during the week of $10-16$ April.

During llay, 11ght trap collections were continued on a weekly basis. Results of tarsalis collection are shown in Table 2.

A trospharic temperatures of below freezing were recorded throughout most of Uarch and April. Saximum temperatures, for any one day, gradually cllmoed linto the $70^{\circ} \mathrm{s}, \mathrm{F}$, wh the average temperature fluctuating 
between $48^{\circ}$ to $51^{\circ}$ \% (Figure 2).

Soll teaperatures fluctunted very little arter the abmut rien frow $34^{\circ} \mathrm{F}$ of aroh 5 to $51^{\circ}$ at April 26 experienced just pravioun to enargence (Figuro 3$)$.

\section{Laboratory oaervationa}

Examination of dissected specimens from field collections of hibernating wooqultoes showed that hibermating c. taraila coaplotely Lacked develoging ove or undigented blood. The mbdomen of wech specisen, however, was fllled with fat bodiss. In apecinons oellected and kopt alive at $40^{\circ}$ y for twenty four hour and those kept allwo at $40^{\circ}$ \% for two weaks very 21ttle differenoe in mount of abdoulnal rat noted. Seanonally, howover, specians collocted during harah whomed less bodoainal fat bodies than opeeimans collooted in lovember and December.

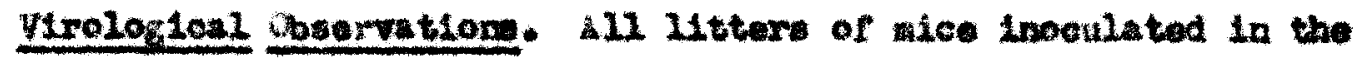
attonpt to 1eolate wise virum appeared healthy on the fourteenth day following inoeulation. Firologleal results were reosded as nagative (Table 1). 


\section{DISOUSSIOH}

The hibernation habitat of Gulex tarsallo is Virtually unknom in nost areas where winters are severe. Hibernation in artificlal shelters has been described in food storage cellar (Loner, 1952) Smith, 1955, Dow et al, 2956), whe unafte (BLackmore and inn, 1956, Dow et al., 1956) and sub-floor spaces (aush te ․․, 1956). Present evidence, with exoeption of observations in made tunnels of colorado (Blackmore and ing, 2956), indieate that artificlal whelter do not serve as principal hibernation stos. Following investigation of food torage cellars and wine shafts in korthern Dtah, Dow et al." (1956) cowsent, "If Gulex tarealls overwinters sucoessfully in mine ahafts, it survives in spite of excessively high mortelity. It seems more 1ikely that the normal winter hastat is yot unknown." Investigation of notural habitats from which hibernation has been reported in Californis (Hortenson, 1953) revealed rodent burrows ahelter a fow specimens in Colorado (Bennington et 21., 1950). Ht present, evidence sesms to indicate rodent burrows are not a jor hibarnaton hasitat although more research is being done to accurately evaluate these sites. Realluing that the C. tarsalis htbernated long before artiflaial shelters played an iaportant role in tarsalis bionomics, kuah et $1 .(1958)$ began a comprehensive earch of the Columbia kiver Basin to loeste natural hibernation habltats. They dlsoovered the first jor natural habltate in cold northern ollmate and deseribed them as rock piles at the base of volaanic outarops. Taylor (1959) reported finding tarsalis in taluo 
slides near the base of mountains surrounding Utah Valley during the early spring, but before detalled observations could be made energence had been completed. Evidence gathered during the present study confirms Taylor's (1959) supposition that talus slopes at the base of the mountains are typical hibernation habitats for $\mathrm{C}$. tarsalis in Utah Valley. The behavior of tarsalis prior to hibernation was studied very closely in Colorado by Bennington et al. (1958). Sumarizing their obser witions they coment,"...Culex tarsalis females from late summer and fall broods mate, take plant julce, and enter a dlapause wh respect to blood feeding to develop fat bodies." During the present study no attempt was made to distinguish between broods. In all specimens taken in sweep-net collections during September and the flrot week of Dctober, a decline from $23 \%$ to $4 \%$ in number of specimens showing blood was noted. Fat body development increased from $2 \%$ to $87 \%$ during this same period with all female specinens collected after 10 October showing definite fat body development in the abdomen.

Present evidence indicates that $\underline{C}$. Hrsalis does not go into hibernation engorged wh blood. This supports the concept that it would bo unlikely for mosquitoes to go into hlbernation with a virally infectod blood meal. The stimull which caused the mosquitoes in this atudy to discontime taking blood meals and develop abdoninal fat bodies were not investigated; however, there as abservec correlation between this behavior and the decrease in minimum atmosfheric temperatures. Movement of $\mathrm{C}$. tarsalis in and out of the hibernation habitat during the fall appeared to be stinulated by temperature change. This phenomenon would seem to indicate decreasing minimum temperature is one 
of the factorg stimulating hibernation. On days before true hibernation began specimens appeared in vegetation or on top of the hibernation site when atmospheric temperatures were above $40^{\circ} \mathrm{F}$ and disappeared into the rocks when temperatures fell below this. Movement in and out of the hibernation habitat is an observation new with this present study: however, it has been suspected in Calffornia (keeves et a1., 1958) where tarsalis are seldom found infected durin; the early winter but become infected during the hibernation per1od. Throughout the present study careful observation was made on werm dayis to detect ary movement out of hibernstion site after true hibernation beganj indications are, however, that once tarsalis enters true hibernition they remain until spring.

Mosquitoes are not totally inactive during hibernation. After observalon of hibernating Culex apicalis in las sachusetts, Berg and Lang (1948) state, "There was a noticable activity among the mosquitoes throughout the study period, even during the coldest months..... It was found that no mosquito occupled the same place for more than two weeks". Hovenent by tarsalls during the winter was observed in mine tumels by Dow et al. (1956) and appeared to be correlated with fluctuations in temperature and relative humidity, at least in the early part of their study. Rush et al. (1958) found tarsalis in ruck plles from one to four feet from the surface and found no correlation with depth and temperature because specimens were collected uncler different climatic conditions at the same oite. In consideration of data from the present study it appears that novement to different depths within the talus slopes atimulated by temperature changes in the talus habitat. 
Hosquito hibernation temperatures renained rather constant throughout the winter as specimens moved within the site to maintain temperatures which were destrable (F1gure 3).

The range of temperatures in which hibexnation of $\mathrm{C}$. tarsalis occurs Is apparently wide (FIgure 4). Dow et a1. (1956) postulate, "If the source of this energy is food stored in the body and if this supply must last through the winter, the species should best aurvive in natural shelters where it would be inactivated by the cold and not trapped by the heat." Previous workers studying hibernation in artificial shelters found $\mathrm{C}$. tarsalis hibernating in tempratures above freezing. Rush et a1. (1958) durling observations of rock p1las in the Columbia River Basin state," . .there is Iittle doubt that at least part of the rock-pile population was occasionally exposed to below-freezing, if not below zero temperatures." Data gathered curing the present study indicates . . tarsalis hibernate at temperatures nesr freezing $\left(29-38^{\circ} \mathrm{F}\right)$, and when temperature changes occurred within the habitat they responded by moving deeper or nearer the surface of the talus slope to find sultable conditions.

The principal factor stimulating spring gmergence from hibernation appears to be a continued increase in temperatiure within the hibernation habitat. Bennington et al. (1958) and Benning;on and Sherman (1960) present evidence wich indicates C. tarsalis J'emales emerge frum hibernation shortly following the spring soil temperature inversion. Dow et al. (1956) state," . . it appears that increasing out-door temperatures might have increased the temperatures within the tunnel so that . taralis were forced out of Its shelter." Data gathered 
during the present study indicate that a rise in temperature within the hibernation habitat and not atasosheric tempe:sture alone stimulates emergence from hibernation. Keener (1952) observed that emergence did not occur until daily minimum temperatures were maintained above freezing; however, in Washington (Rush et al., 1958) found that tarsalis emerged when minimum temperatures were in the $20^{\circ}, \mathrm{F}$ and maximum in the $60^{2}$ 's F. During the spring of 1960 mergence occurred in Utah Valley during a period when atmospheric temperatures ranged from $18^{\circ}-64^{\circ} \mathrm{F}$, near the same range described by Dow et al. (1756) in Northern Utah, wich $12^{\circ}-55^{\circ} \mathrm{F}$.

Observation during the first month folloring emergence seem to Indicate that $\underline{G}$. tarsalis females are Inactive for nine to eleven days irmediately following emergence from hibernation. Rush et al. (1958) observed engorgment to begin elght to ten days following emergence and Taylor (1959) collected specimens on the fourteenth day fallowing omergence. Considering third instar larvae were collected twenty one days following detection of emergence and seven days after collection of the first engorged specimens it appears eithir blood feeding began earlier then 4 April or the mosquitoes began emmence earlier than 20-21 Garch 1960. Data presented by other invesitigators (Rush et al." 1958; Taylor, 1959) Indicate a period of about lien to fourteen days must elapse before blood feeding begins, thus irdicating that omergence in Utah Valley during 1960 began about two weeks before 1t was detected. The failure to isolate weE viruses from the limited number of hibernating specimens examined is not significant when considered alone. These data do, however, add to accumulating evidance that Culex tarsalis 
does not serve as the principal mechanism for the survival of viruses during the winter months. 


\section{CONCLUSIONS}

On the basts of this study the following conclusions are presented:

1. Culex tarsalis began preparation for hibsrnation during the early fall by a decline in blood feeding and sibsequent development of abdominal fat bodies indicating blood enyorged specimens do not enter hibernation.

2. Evidence fron this study supports Taylor's (1959) contention that talus slopes and rook plies are typical natural hibernation habitats of Culex tarsalis in Utah Valley. The present study found hibernating specimens to occupy a level in the hibernation habitat below the frost line and directly beneath a layer of rook molst with frost.

3. Hibernating mosquitoes remalned outside the hibernation habitat during the $\mathrm{fall}$ when atmospheric temperatures were above $40^{\circ} \mathrm{F}$. During warm afternoons in late September and October tarsalis was observed to migrate to the slope appa:ently as a response to decreasing atmospheric temperatures.

4. True hibernation began during the first wisek of November when atmospheric temperatures ranged from $15^{\circ} ; 060^{\circ} \mathrm{F}$. Hibernation durlng this study appeared to be stimulatad by continued decreases in minimum atmospheric temperatures.

5. Hibernating tarsalis morphologically apper red as adults newly energed from pupation. The abdomen of each specimen was filled with fat bodies; however, there was no indication of developing 
ova or undigested blood.

6. Data gathered during this study indicate that targalls hibernates in natural shelters at temperatures near freezing $\left(29^{\circ}-38^{\circ} \mathrm{F}\right)$. when temperature changes occurred within the hibitat the mosquitoes moved deeper or nearer the surface in the talus slope to find conditions sultable for hibernation.

7. Hergence from hibernation first obse:-ved on 22 karch. Emergence appeared to be stimulated by inoreasing temperatures within the hibernation habitats.

B. Larvae first appeared in American Fork on 11 April 1960.

9. Emergent hibernators do not actively seek a blood meal for ten to fourteen days following emergence.

10. Twenty three pools (2l2 mosquitoes) of hikernating Culex tarselis collected during this study wore not infected by western oquine encephalomyelitic (MLE) vimuses. 


\section{REFERENCIS CITED}

Bennington, E.E., Blackmore, J.S. and Scooter, C.A. 1958. "So11 Temperatures and Emergence of Culex tarsilis From Hibernation," Mosquito News, 18 (4): 297-298.

, Scooter, C.A. and Baer, Harold 1958. "The Diapause in Adult Female Culex tarsalis coquillett (Iiptera, Culacidao)," Mosquito News, $18(4): 299-304$.

, and Sherman, Ida L. 1960. "A Nate or Reported Cases of Encephalitis and Soil Temperatures in Colorado," Mosquito News, $20: 34-37$.

Berg, thorris and Iang, Sheldon 1948. nobservations of Hibernating kosquitoes in Massachusetts," Mosquito News, 8: 70-71.

Blackmore, J.S., and Winn, J.F. 1956. "A Wint:r Isolation of western Equine Encephalitis from Hibernating Culec tarsalis Coquiliett," Proceedings of the Society of Experimenta[ Blology and Hedicine, 91: 146-148.

Dow, Richard P., Mail, G. Allen, and Richards, (..S. 1956. NObservations on the Overwintering of Culex tarsalis in Northern Utah," Proceedings of the Winth Annual Meetings of the Utah losquito Abatement Tsociation, pages 12-15.

Ecklund, Carl H. 1960. "Insect-Borne and Anima]-Borne Virus Diseases of Man," Minnesota Hedicine, 43:184-189.

Hammon, 篗. HCD., and Reeves, W.C. 1947. "Interepidemic Studies on Arthropod Borne Virus Encephalitides and Polionyelitis in Kern County, California, and the Yakima Valley, Washington, 1944," American Journal of Hygiene, $46: 325-335$.

- Reeves, W.C., and Gjullin C.M. 1942. MLosquitoes and Encephalitis in the Yakima Valley, Washington, V. Sumary of Case Agalnst Culex tarsalis Coquiliett as a Vector of the St. Louls and Western Equine Viruses," Journal of Infectious Disease, 70: 278-283.

, Reeves, W.C., Beener, S.R. and Brookmau,, B. 1945. "Human Encephalitis in the Yakima Valley, Washingi:on, 1942, With FortyNine Virus Isolations (gestern Equine and sit. Louls Types) From Mosquitoes," Journal of the Imerican fedice I Issooiation, 128: 1133-1139. 
, Reeves, W. C., and Calindo, P. 1945. "Epidemiologic studies of Encephalitis in the San Joaquin Valley of California, 1943, with the Isolation of Viruses from Mosquitoes," Arerican Journal of Hygiene 42: 299-306.

Hess, A. D., and Holden, Preston 1958. "The Natural History of the Arthropod-Borne Encephalitides in the Untted States," Annals of the New York Acadery of Science, 70 (Article 3): $294-31$.

Keener, George G., Jr. 1952. "Observations on Overwintering of Culex tarsalis oquillett (Diptera, Culicidae) in Western Nebraska," Mosquito Hews, $12(3)$ : 205-209.

Loom1s, E. C., and Green, D. H. 1954. "Resting Habits of Adult Culex tarsalls Coquillett 17 San Joaquin County, California, November 1953 through November 1954, A Preliminary Report, "Proceedings and Papers of the Twenty Third Annual Conference of the California Mosquito ControI Association. pages I25-127.

E. C., and Greei D. H. 1959. "Ecological Observations on Culex tarsalis Coquillett and Other Hosquitoes in the Delta Region of the Central Valley of California, 1953-1956 (Diptera: Culicidae)," Annals of the Entomological Society of America, 52:524-533.

Mortenson, Earl W. 1953. Observations on the Overwintering Habits of Culex tarsalis Coquillett in Nature,". Proceedings and l'apers of the Twenty First Anmal Conference of the Californila Kosquito Control Association. pages 59-60.

Reeves, W. O., Bellany, R. E., and Scrivant, R. R. 1958. "Relationships of Losquito Vectors to inter Survival of lncephalitis V1ruses, I, Under Natural Conditions," American Journal of Hygiene, 67:(I) $78-89$.

, Washburn, G. E., and Hamon WaD. 1948. Western Equine Encephalatis Control Studies in Kern County Calffornis 1945 . I. The Effectiveness of Residual D.D.T. Deposits on Adult Culex Mosquito Populations," American Journal of Hygiene, 47:82-9I.

Rush, 两. A., Brennan, J. K., and Ecklund, O. K. 1958. "A Natural Hibernation Site of the Mosquito Culex tarsalis Coquillett in the Columbla River Basin, Washington," Wosquito News, 18(4): $288-293$.

Smith, J. V. 1955, "Unpublished Observations on the Overwintering Habits of Culex tarsalis Coquillett in Milk River Valley of Wontana," Sumary of Investigations, CDC. Technology Branch, No. 8 (US Department of Health, Education and Welfare publlc Health Service Comminicable Disease center): $221-223$. 
Taylor, Stanley K. 1959. Bionomics of Culex tarsalis Coquillett in Utah County. Unpublished Kaster's Thesis, Departmant of Zoology and Entomology, Brigham Young University. 


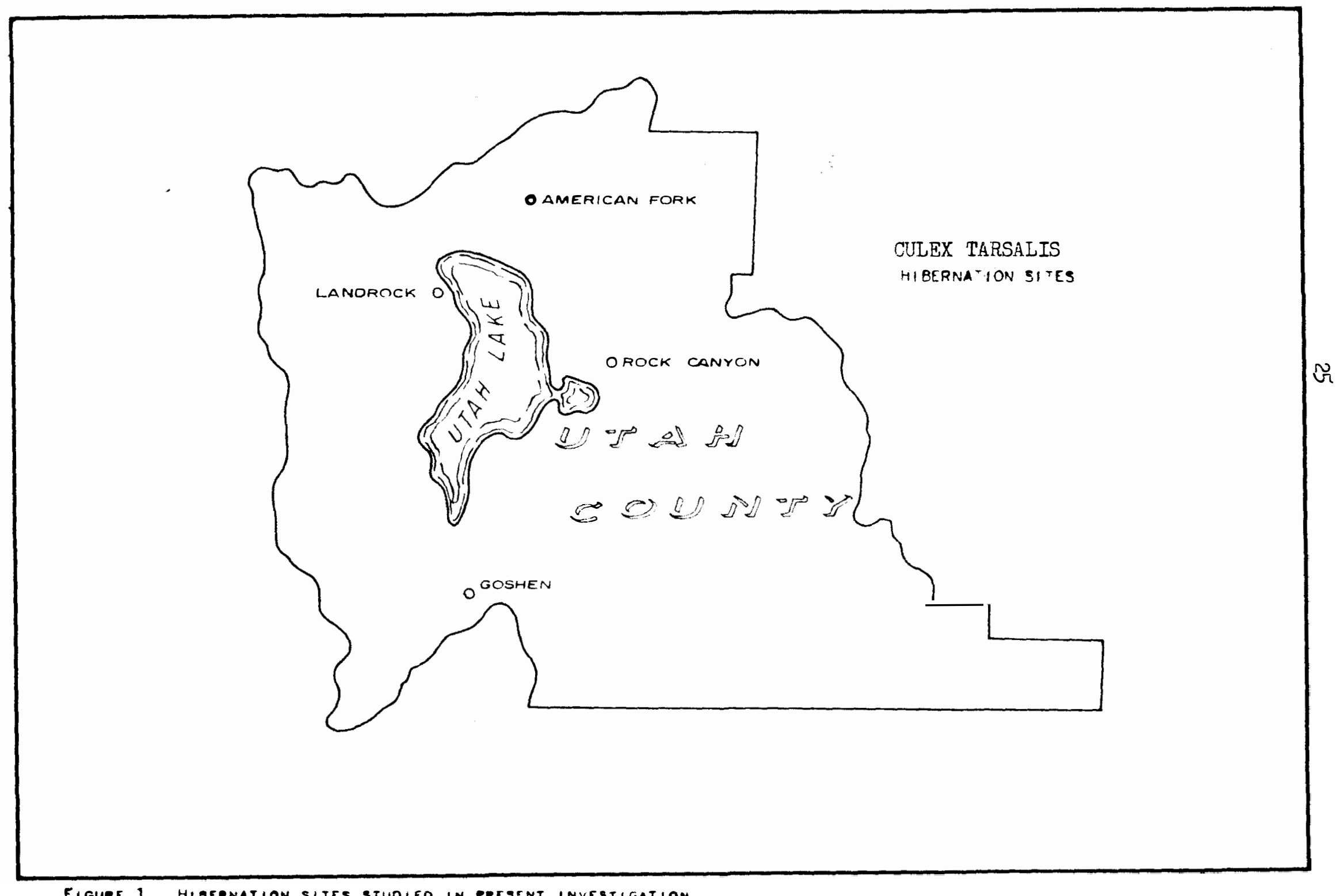

FigURE 1. HIBERNATION SITES STUDIEO IN PRESENT INVESTIGATION. 


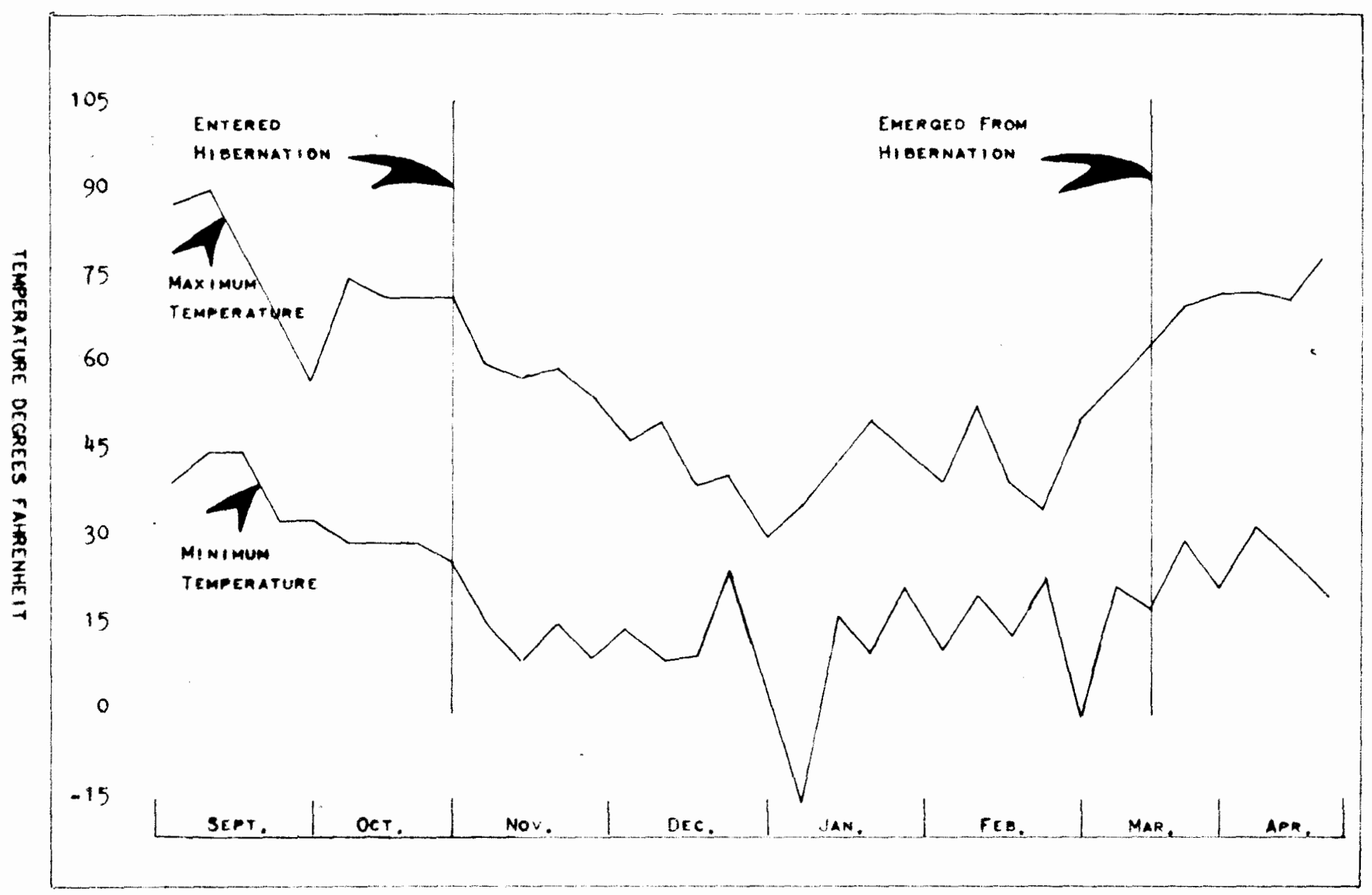

FiguRe 2. Maximum and minimum atmospheric temperatures taken at the menornhall Ranch one mile noRth of Landack dURING months indicated, 1959-1960. 


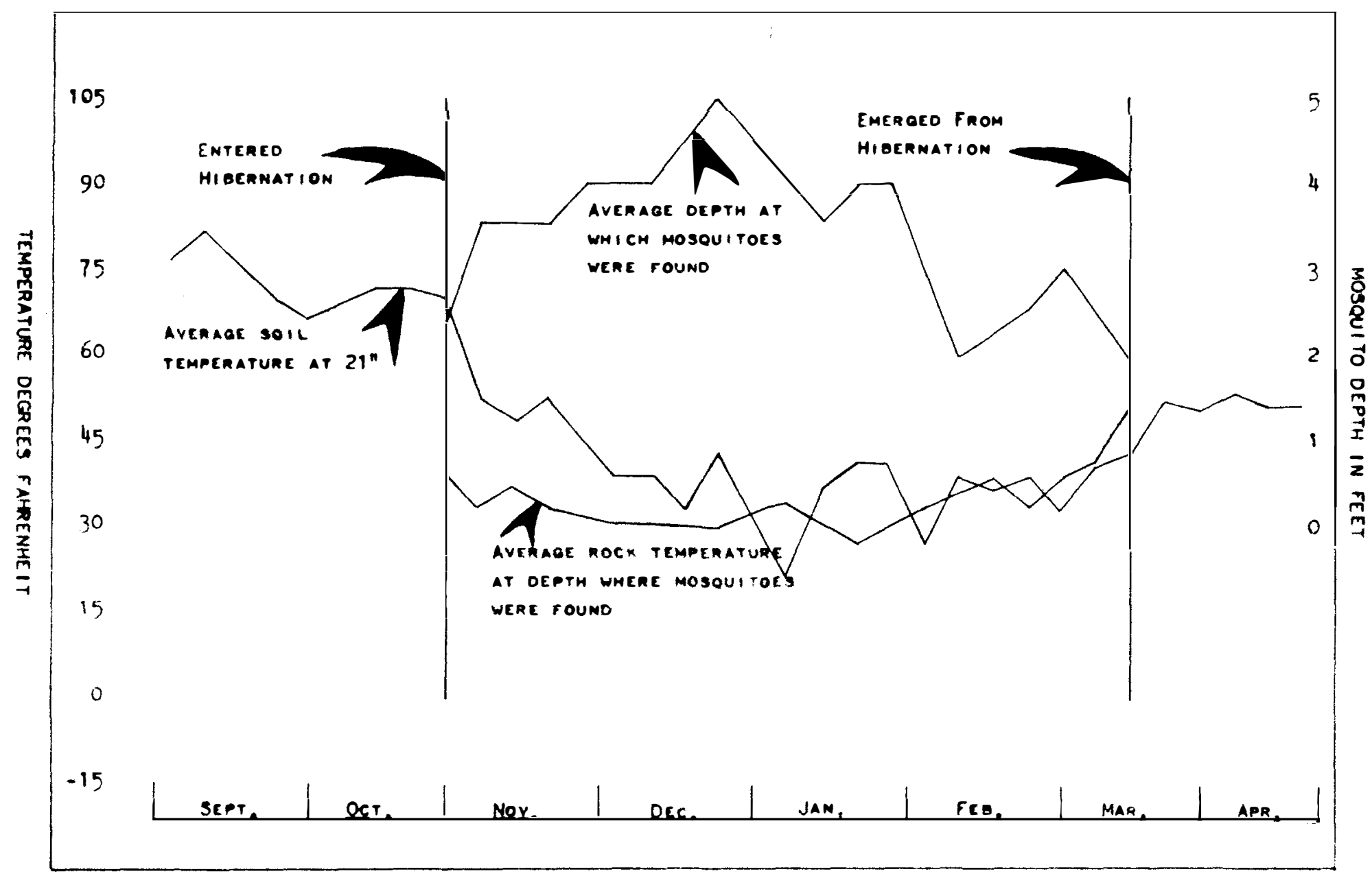

figure 3. Intenkelationship of average goll temperatuae at the 21-inch level, average MOSQUITO-ROCK TEMPERATURE AMO DEPTH OF HIBERMATING SPECIMENS. 


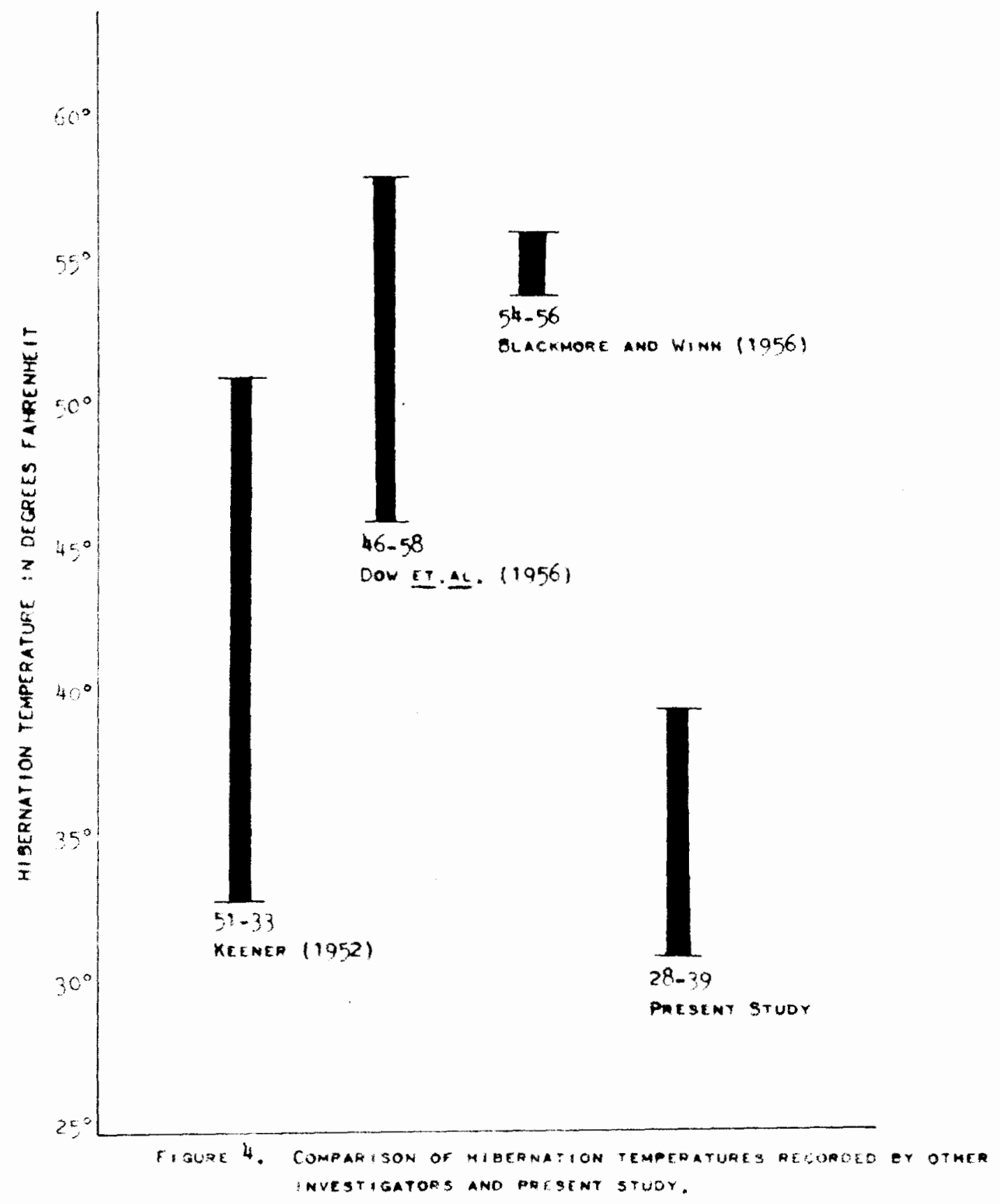




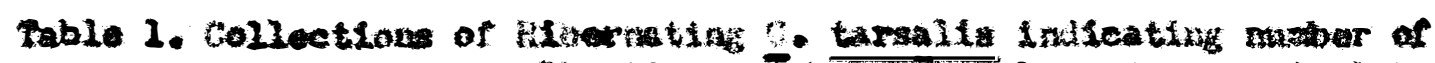

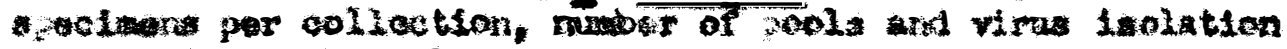
results for ach pool

\begin{tabular}{|c|c|c|c|c|}
\hline 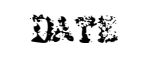 & $2, x+5$ & 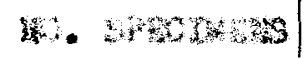 & \$o. Wots & 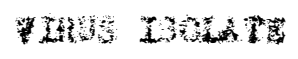 \\
\hline 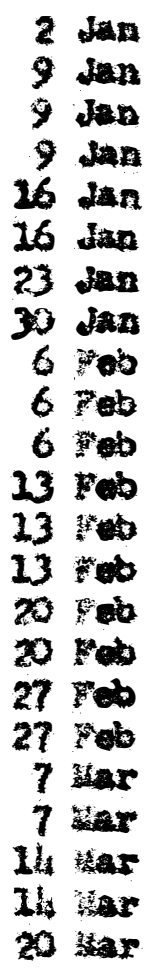 & 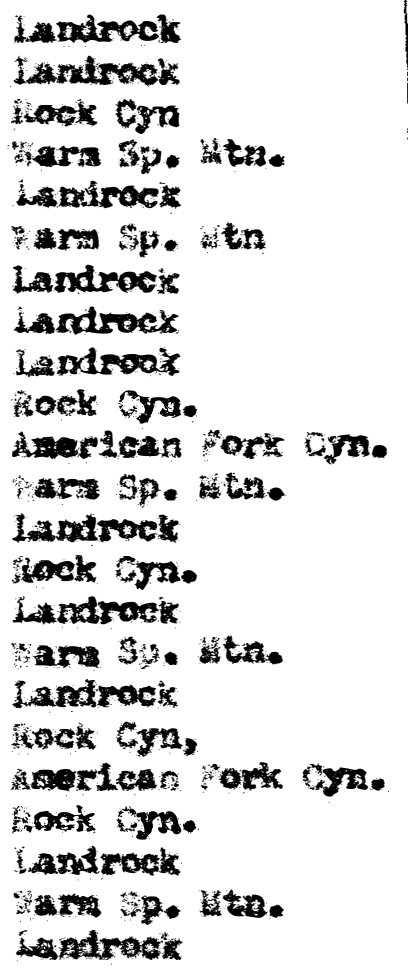 & $\begin{array}{r}7 \\
8 \\
7 \\
7 \\
10 \\
9 \\
10 \\
10 \\
10 \\
9 \\
7 \\
12 \\
6 \\
7 \\
13 \\
11 \\
9 \\
20 \\
11 \\
7 \\
9 \\
20\end{array}$ & $\begin{array}{l}1 \\
1 \\
1 \\
1 \\
1 \\
1 \\
1 \\
1 \\
1 \\
1 \\
1 \\
1 \\
1 \\
1 \\
1 \\
1 \\
1 \\
1 \\
1 \\
1 \\
1 \\
1 \\
1\end{array}$ & $\begin{array}{l}- \\
= \\
= \\
= \\
= \\
= \\
= \\
= \\
= \\
= \\
= \\
= \\
=\end{array}$ \\
\hline
\end{tabular}


Table 2. Light trap eollections of $c$. tarsalla

at Joghen and the wendenhaT1 Fanch 1960.

\begin{tabular}{|c|c|c|}
\hline DATE & NUSB WOLLATH & Lockston \\
\hline $\begin{array}{l}30 \text { March } \\
2 \text { April } \\
3-9 \text { April } \\
3-9 \text { April } \\
10-16 \text { ApriI } \\
10-16 \text { ApriI } \\
17-23 \text { April } \\
17-23 \text { ApriI } \\
24-30 \text { Apri1 } \\
24-30 \text { ApriI } \\
1-7 \text { May } \\
1-7 \text { Hay } \\
8-14 \text { Hay } \\
8-14 \text { May } \\
15-20 \text { May } \\
15-20 \text { Hay }\end{array}$ & $\begin{array}{r}3 \\
2 \\
1 \\
2 \\
3 \\
5 \\
1 \\
2 \\
0 \\
1 \\
1 \\
0 \\
2 \\
3 \\
8 \\
10\end{array}$ & 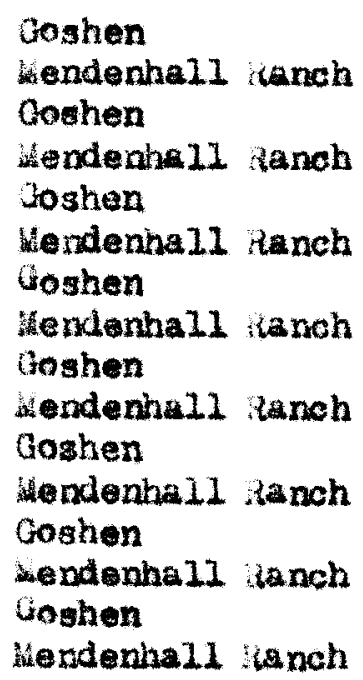 \\
\hline
\end{tabular}




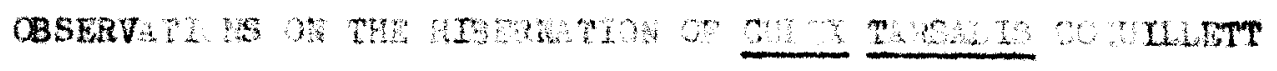

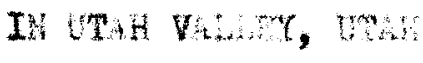

\author{
sa Abatract of a Thesis \\ resented to the \\ Department of zoolowy and intomology \\ 3 righam Young iniversity \\ In Partial Fulfillnent \\ of the vequrementa for the vatree \\ haster of Belence \\ by \\ Dennis . Trent \\ Soptenber 1760
}




\section{ABs PraC:}

The mosquito Culex tarsalis is we principal naturaliy infected veetor of western equine encephalitic (Whilis) viruses. Certain interrelationshios of $\mathrm{g}$ g epidemiology and tarsalis bionomica are besally underatood, however, in areas mer wintera are severe little is known of targalis hibernation and the overwintering fochanism for the is yet unicnown. An understanding of the interrelationghip of thea two phenomena is essentlal to an accurate evaluation of the mosquito-Xist virus overintoring reservoir concept. The purpose of this study was to gather ocologieai information on the hibermation of Gulex tarsalis In Utah Valley, and secondily to collect poola of nibernating tarsalis and deterwine the index of Intection by wit viras.

Four representative talus lopes in Utun Valloy were seicoted for extensive study durin the fall, winter and ourly spring periods. Systematic observations were made during the fall and winter to determine behavior and presexce and to outain opecimens for viral analysis. Dotection of early wins mevaent from hiberntion wa accomplished by oresuation and light trap collections.

Durine the fall targalis remained outside the hibernation habitat wen atmospherio temperature ware bove $40^{\circ} \mathrm{y}$ and moved to cocupy a ponition under top rocks of the site when temperataras fall below $40^{\circ} \mathrm{F}$. The number of spectwens abowing blood angorgement declined from $23 \%$ to 4 durlus the fall with a subsequent increase in fat body development from 2 to $67 \%$. These date sem to indicato tinet $\mathrm{g}$. tarsalis 
does not onter hibernation in an ongorged condition. Truo hibernation began during the first we of kovember wen atwospheric terperatures $\operatorname{ran}_{\mathrm{s}}$ ed from $15^{\circ} \mathrm{F}$ to $60^{\circ} \mathrm{F}$ and appeared to be stimulated by contirued decrease in atmospherlo tenperature. Hibernating specimens were found clinging to the underside of rocks below the frost line and directly below a layer of rocks moist with frost. Fearales appeared as newly pupatad adults, the abdomen of each specimen filled with fat bolles; howsver, there nas no indication of undigested bloot or ceveloping ova. Tarsalis hibernated at terversture near freesing $\left(29^{\circ} 30^{\circ}\right)$ and moved deeper or nearer the suriace of the talue slope to matatain sultabie hibernition conditions.

Hargence from hibernation detected on 22 harch and appeared to be stimulated by increasins texperatures wathin the hilernation habltat. Light trap and chickan coos collections indicato tarsalis appareatly does not seek a blood menl for approxinately fourteen days after emergence fron hibernation. Wrat larve woro collocted on 21 April 1960.

Twenty three pools (212 nosquitoes) of bibernating $\mathrm{C}$. tarsalis

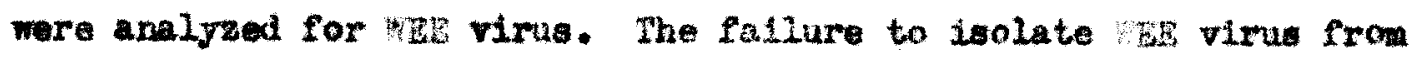
this limited number of specimens is not stguificant when considered alone; however, these det do add to accuralating evidence suggesting C. tarsalis does not aerve as the principal overwintering mectinism for WTE virus. 
does not enter hibernation in an engorged condition.

True hibernation begen during the first week of November when atmospheric temweratures ranged from $15^{\circ} \mathrm{F}$ to $60^{\circ} \mathrm{F}$ and appeared to be stimulated by contimed decrease in atmospheric tomperature. Hibernating specimens were found clinging to the underside of rocks below the frost ine and directly below layer of rocks moist with frost. Females appeared as newly pupated adults, abdomen of each specimen filled with fat bodles; however, there was no fudication of undigested blood or developing ova. Parsalis hibernated at tenperatures near freezing $\left(29^{\circ}\right.$ to $\left.38^{\circ} \mathrm{F}\right)$ and moved deeper or nearer the sur face of the talus slope to maintain sultable hibernation conditions.

Emergence from hibernation was detected on 22 Marcis nd appeared to be stimulated by increasing temperatures within the hibernation habitat. Light trap and chicken coop collections indicate tarsalis apparentiy does not seek a blood meal for approximately fourteen days after emergence from hibernation. First larvae were collected on 11 ApriI 1960.

Twenty three pools (212 mosquitoes) of hibernating G. tarsalis were analyzed for $\sqrt{ } \mathrm{BE}$ virue. The failure to isolat wat virus from this linfted number of specimens is not significant when considered alone; however, these data do add to accumalating evidence suggesting C. tarsalis does not serve as the principal overwinterin. - hanism for WEE virus. 
Approved: 